which congress at Berlin, although proposed for I895, nothing has been done or prepared, so far as I know, although I worked in the Berlin botanic museum till last October.-OTт0 Kuntze, San Remo, Italy.

\title{
Dates and references, and priority in nomenclature.
}

It does not seem too much to expect from those who would purify botanical nomenclature, that they should be them. selves pure. But those who have had to do with comparing references with the originals, will be surprised at the enormous number of inaccuracies that pass current. A new reference book is required as badly as a purified nomenclature. In the preparation of the chapters to go with the plates in $\mathrm{my}$ "Flowers and Ferns of the United States," and its continuation, "Meehans' Monthly," I have tried to verify original references, and can say of my own personal knowledge that ref. erences to dates and authors are in a most deplorable condition.

I am just now at work on the two species of Chimaphila, C. umbellata and C. maculata. My good friend Conway MacMillan contends in the "Metaspermæ of the Minnesota Valley" that we must drop Chimaphila of Pursh (1814), and adopt Pseva of Rafinesque," Jour. Phys. 79: 26r. I809. turn to "Index Kewensis," and find it is "Jour. Phys. Sc." thus indicating that it may be an English title, but there is no such work. I try again and examine the work usually referred to as "Jour. Phys.," Desvaux "Journal de physique," and examine page $26 \mathrm{r}$, volume 79 , but there is not a word about Rafinesque or botany. Looking again at "Index Kewensis," I suspect an error in adding "Science" to the title, and note that they give 1819 for the date, instead of 1809 . Examining "Journal de Physique" for that year, I find a paper by Rafinesque entitled "Remarks critiques et synonymiques sur les ouvrages de MM. Pursh, Nutt.,"-and a host of others - "sur les plantes des Etats-Unis." These authors are handled without gloves, and one can hardly wonder at the coolness shown to him by his co-laborers. "Ipomopsis $\mathrm{Mx}$. abominable name." Mahonia should be changed "as dedicated to a gardener who does not merit the honor." "Lyonil should be changed as it is too near Allionia." "Epifagls Nuttall, is an absurd name." The whole paper is simply a
critique, with no pretension of describing anything. But 
there is a reference to "Pseva." "Chimaphila Pursh is Pseva Raf. Obs., but the name of Pursh is better and more significant." This is all, and this is the authority of "Index Kewensis" for the name.

A clue is at length furnished by Rafinesque's own work "Medical Botany," under Pyrola maculata. "The genus must be divided into sub-genera: Streptylia, Orthylia, Psiseva and Chimaphila." Under Psiseva he would only retain $P$. maculata, even as a subgenus. For this name he quotes Raf. I808. Prof. MacMillan has Pseva I 809. I can find nothing in 1808 relating to it. But there is another reference, "ObServations on some plants of the United States in Medical Repository for I 809." I cannot find this. If it be here that the name was first employed, we have Rafinesque misquoting his own date!

Just here comes in another matter: how far may we be justified in changing an evident error in orthography in an author's name? Those who are acquainted with Rafinesque's handwriting as I am, know how difficult it is to determine the individual letters, and how fond he is of abbreviations. It is no wonder the printer set up Scoria for Hicoria. In the article cited from Desvaux “Journal de Physique," Dr. Torrey is criticised through the chapter as Dr. Jorrey. He seems, however, generally, to accept these printed versions of his manuscripts. Pachistima, if it had been employed by Nuttall or Pursh, he would have characterized as "absurd" or "abominable," and suggested something else. Meisner corrected it subsequently to what Rafinesque's manuscript no doubt intended, Pachystigma, but no one follows it.

By the form Psiseva, which he uses in "Medical Botany," I have little doubt he intended to name this plant after its Indian name Pipsisewa, but that the printer in despair at the manuscript, rendered it Pseva, an "absurd and meaningless" name; or, likely as not, he may have writted P'seva. formers and this is what I want to emphasize-ought not rethis to reform along the whole line, and not puzzle us in this way?-THOMAS MEEHAN. 


\section{$2 \mathrm{BHL}$ Biodiversity Heritage Library}

Meehan, Thomas. 1896. "Dates and References, and Priority in

Nomenclature." Botanical gazette 21(2), 90-91. https://doi.org/10.1086/327306

View This Item Online: $\underline{\text { https://www.biodiversitylibrary.org/item/94860 }}$

DOI: https://doi.org/10.1086/327306

Permalink: https://www.biodiversitylibrary.org/partpdf/222576

\section{Holding Institution}

Missouri Botanical Garden, Peter H. Raven Library

\section{Sponsored by}

Missouri Botanical Garden

\section{Copyright \& Reuse}

Copyright Status: Public domain. The BHL considers that this work is no longer under copyright protection.

This document was created from content at the Biodiversity Heritage Library, the world's largest open access digital library for biodiversity literature and archives. Visit BHL at https://www.biodiversitylibrary.org. 